\title{
Penentuan Penerima Beasiswa Unggul Mulia dan Bidik Misi menggunakan Metode SAW
}

\author{
Citra Andriani ${ }^{1}$, Fitri Marisa ${ }^{2}$ \\ ${ }^{1}$ citraandriani123@gmail.com, ${ }^{2}$ fitrimarisa@widyagama.ac.id
}

Program Studi Teknik Informatika, Universitas Widyagama Malang

\begin{abstract}
Please write the abstract in English and Intisari in Bahasa Indonesia around 100-200 words. These instructions give you guidelines for preparing papers for JOINTECS (Journal of Information Technology and Computer Science). Use this document as a template if you are using Microsoft Word 2007 or later. Otherwise, use this document as an instruction set. Define all symbols used in the abstract. Do not cite references in the abstract. Do not delete the blank line immediately above the abstract; it sets the footnote at the bottom of this column.
\end{abstract}

Keywords - SAW, Beasisiwa, simple application

Intisari-Selama ini perhitungan data hasil serangkaian tes tersebut masih menggunakan sistem manual, sehingga kurang maksimal karena dikhawatirkan ada beberapa data yang tidak terhitung ataupun terdapat kecurangan dalam perhitungan. Sehingga berdasarkan hal tersebut, dan dengan kemajuan teknologi dan informasi peneliti bermaksud membuat aplikasi guna mempermudah kinerja pegawai di Universitas Widyagama khususnya dalam menentukan penerima beasiswa Unggul Mulia dan Bidik Misi.

Kata Kunci-SAW,Beasisiwa, aplikasi sederhana

\section{PENDAHULUAN}

Universitas Widyagama termasuk PTS yang menyediakan beasiswa dari dalam kampus yang disebut Beasiswa Unggul Mulia. Ada pula beasiswa Bidik Misi dari pemerintah dan beasiswa lainnya. Untuk memperoleh beasiswa ,maka para calon mahasiswa tersebut mengikuti serangkaian tes. Untuk menentukan penerima beasiswa pihak universitas Widyagama menghitung hasil dari nilai UN, tes tulis, serta hasil wawancara dan survei. Yang kemudian dari serangkaian tes tersebut diperoleh data calon penerima beasiswa. Selanjutnya data tersebut dihitung dan perhitungan tersebut disesuaikan dengan kriteria penerima beasiswa Unggul Mulia dan Bidik misi. Setelah ditemukan data penerima beasiswa Unggul Mulia dan Bidikmisi [1].

Selama ini perhitungan data hasil serangkaian tes tersebut masih menggunakan sistem manual, sehingga kurang maksimal karena dikhawatirkan ada beberapa data yang tidak terhitung ataupun terdapat kecurangan dalam perhitungan. Sehingga berdasarkan hal tersebut, dan dengan kemajuan teknologi dan informasi peneliti bermaksud membuat aplikasi guna mempermudah kinerja pegawai di Universitas Widyagama khususnya dalam menentukan penerima beasiswa Unggul Mulia dan Bidik Misi.

\section{TINJAUAN PUSTAKA}

A. Teknologi

Mendefinisikan mengenai pengertian teknologi sebagai suatu bidang yang berkaitan erat dengan ilmu sains dan ilmu rekayasa atau ilmu engineering [2].

\section{B. Aplikasi}

Aplikasi merupakan sebuah software (perangkat lunak) yang bertugas sebagai frontend pada sebuah sistem yang dipakai untuk mengelolah berbagai macam data sehingga menjadi sebuah informasi yang bermanfaat untuk penggunanya dan juga sistem yang berkaitan [3].

\section{Beasiswa}

Beasiswa Unggul Mulia yaitu merupakan program beasiswa yang diberikan oleh Universitas Widyagama malang bagi calon mahasiswa yang mempunyai prestasi akademik istimewa dan diutamakan bagi yang kurang mampu dari aspek pembiayaan dan masuk pada kelas leguler A (kelas pagi) [1].

\section{Pengertian SAW}

Sistem Pendukung Keputusan (SPK) atau Decision Support System (DSS) adalah sebuah sistem yang mampu memberikan kemampuan pemecahan masalah maupun kemampuan mengomunikasikan untuk masalah dengan kondisi semi terstruktur dan tak terstruktur. Sistem ini digunakan untuk membantu pengambilan keputusan dalam situasi semi terstruktur dan situasi yang tidak terstruktur, dimana tak seorang tahu secara pasti bagaimana keputusan seharusnya dibuat [4], [5].

\section{METODE PENELITIAN}

Paragraf harus teratur.Semua paragraf harus rata, yaitu sama-sama rata kiri dan dan rata kanan.

A. Perancangan Algoritma

1. Peserta melakukan tes masuk

2. Panitia menerima berkas test dan menhitung nilai test

3. Nilai dihitung dengan metode SAW 
4. Hasil dari perhitungan metode SAW dikelompokkan berdasarkan kriteria penerima beasiswa

\section{B. Flowchart}

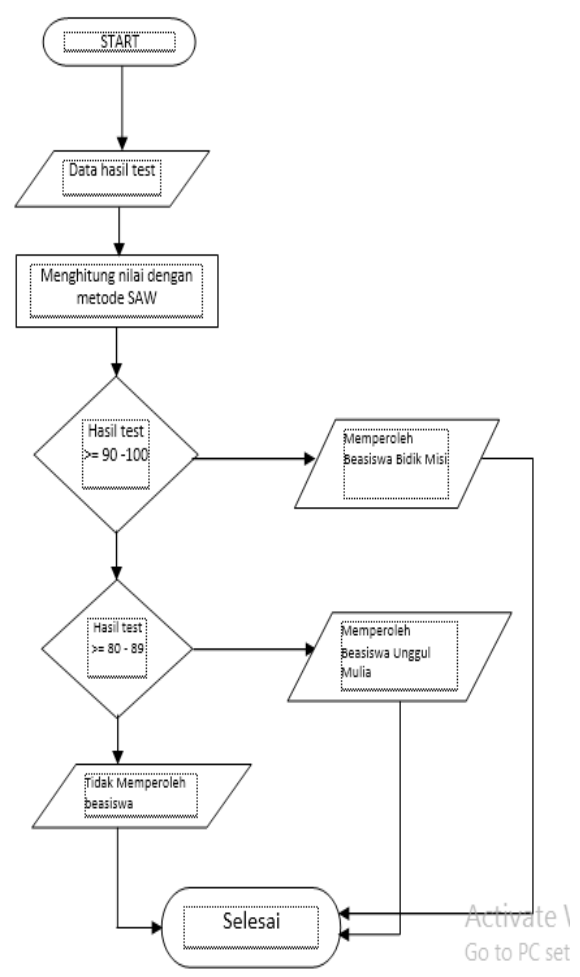

Gambar 1. Flowchart Penentuan Beasiswa

\section{Rumus Sederhana SAW}

Metode SAW sering juga dikenal sebagai metode penjumlahan terbobot. Konsep dasar metode SAW adalah mencari penjumlahan terbobot dari rating kinerja pada setiap alternatif pada semua atribut. Metode SAW membutuhkan proses normalisasi matriks keputusan (X) ke suatu skala yang dapat diperbandingkan dengan semua rating alternatif yang ada.

$$
\begin{aligned}
& \mathrm{r}_{i j}=\frac{x_{i j}}{\operatorname{Max}\left(x_{i j}\right)} \text { Jika j adalah atribut benefit. } \\
& \mathrm{r}_{\mathrm{ij}}=\frac{\operatorname{Min}\left(x_{i j}\right)}{x_{i j}} \text { Jika j adalah atribut cost. }
\end{aligned}
$$

Dimana $r_{i j}$ adalah rating kinerja normalisasi dari alternatif $A_{i}$ pada atribut $C_{i} ; \mathrm{i}=1,2,3, \ldots, \mathrm{m}$ dan $\mathrm{j}=1,2,3, \ldots, \mathrm{m}$. Nilai preferensi alternatif $\left(V_{i}\right)$ diberikan sebagai :

$$
\mathrm{V}_{\mathrm{i}}=\sum_{j=1}^{n} w_{j} \boldsymbol{r}_{i j}
$$

Nilai $V$ yang lebih besar, mengindikasikan bahwa alternatif $A_{i}$ lebih terpilih

\section{Penerapan}

Universitas Widyagama akan memilih calon mahasiswa baru yang memperoleh beasiswa Unggul Mulia atau Bidik Misi. Ada empat kriteria yang digunakan untuk melakukan pemilihan, yaitu :

1. $\mathrm{C} 1=$ Test Potensi Akademik

2. $\mathrm{C} 2=$ Test Psikologi

3. $\mathrm{C} 3=$ Wawancara

4. $\mathrm{C} 4=$ Survei

Pengambil keputusan memberikan bobot untuk setiap kriteria sebagai berikut : $\mathrm{C} 1=35 \% ; \mathrm{C} 2=15 \%$; $\mathrm{C} 3=15 \%$; $\mathrm{C} 4$ $=35 \%$. Ada beberapa orang mahasiswa yang dijadikan ilustrasi dalam perhitungan ini.

$$
\begin{aligned}
& \text { A1 }=\text { Budi, } \\
& \text { A2 }=\text { Boni, } \\
& \text { A3 = Ronal }, \text { dan } \\
& \text { A4 = Fajar }
\end{aligned}
$$

Tabel 1. Nilai alternatif di setiap kriteria

\begin{tabular}{|c|c|c|c|c|}
\hline \multirow{2}{*}{ ALTERNATIF } & \multicolumn{5}{|c|}{ KRITERIA } \\
\cline { 2 - 5 } & C1 & C2 & C3 & C4 \\
\hline Budi & 70 & 60 & 80 & 85 \\
\hline Boni & 70 & 80 & 80 & 65 \\
\hline Ronal & 60 & 90 & 70 & 80 \\
\hline Fajar & 75 & 80 & 65 & 90 \\
\hline
\end{tabular}

Tabel 2. Proses penyelesaian

\begin{tabular}{|l|l|l|l|}
\hline$R_{11}=70 / 75=0,93$ & $R_{21}=70 / 75=0,93$ & $R_{31}=60 / 75=0,8$ & $R_{41}=75 / 75=1$ \\
$R_{12}=60 / 90=0,67$ & $R_{22}=80 / 90=0,89$ & $R_{32}=90 / 90=1$ & $R_{42}=80 / 90=0,89$ \\
$R_{13}=80 / 80=1$ & $R_{23}=80 / 80=1$ & $R_{33}=70 / 80=0,86$ & $R_{43}=65 / 80=0,81$ \\
$R_{14}=85 / 90=0,94$ & $R_{24}=65 / 90=0,72$ & $R_{34}=80 / 90=0,89$ & $R_{44}=90 / 90=1$ \\
\hline
\end{tabular}


Tabel 3. Hasil perhitungan

Proses perankingan dengan menggunakan bobot yang telah diberikan ole pengambil keputusan: $\mathbf{w}=[0,35,0,25,0,0,25,0,15]$. Hasil Yang diperoleh adalah sebagai berikut :

$\begin{aligned} \mathrm{V} 1 & =(0,35)(0,93)+(0,15)(0,67)+(0,15)(1)+(0,35)(0,89) \\ & =0,3255+0,1005+0,15+0,3115 \\ & =0,8875=0,89 \\ \mathrm{~V} 2 & =(0,35)(0,93)+(0,15)(0,89)+(0,15)(1)+(0,35)(0,22) \\ & =0,3255+0,1335+0,15+0,252 \\ & =0.861=0,86 \\ \mathrm{~V} 3 & =(0,35)(0,8)+(0,15)(1)+(0,15)(0,86)+(0,35)(0,89) \\ & =0,28+0,15+0,129+0,3115 \\ & =0,8705=0,87 \\ \mathrm{~V} 4 & =(0,35)(1)+(0,15)(0,89)+(0,15)(0,81)+(0,35)(1) \\ & =0,35+0,1335+0,1215+0,35 \\ & =0,955=0,96\end{aligned}$

\section{HASIL DAN PEMBAHASAN}

Tabel 4. Perhitungan pada Excel dengan data yang sama pada perhitungan manual

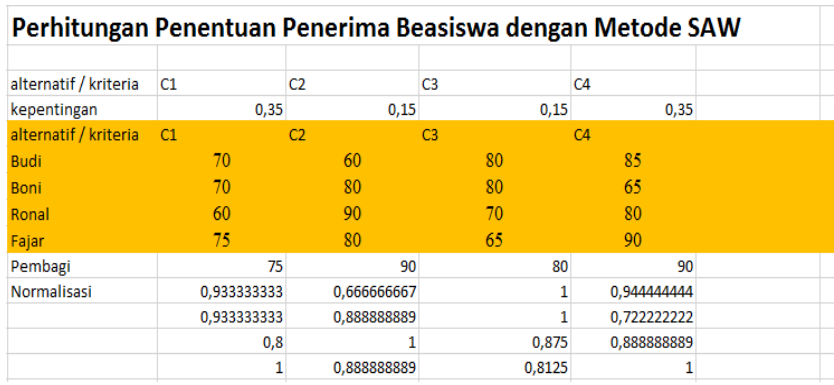

Tabel 5. Rumus dalam excel

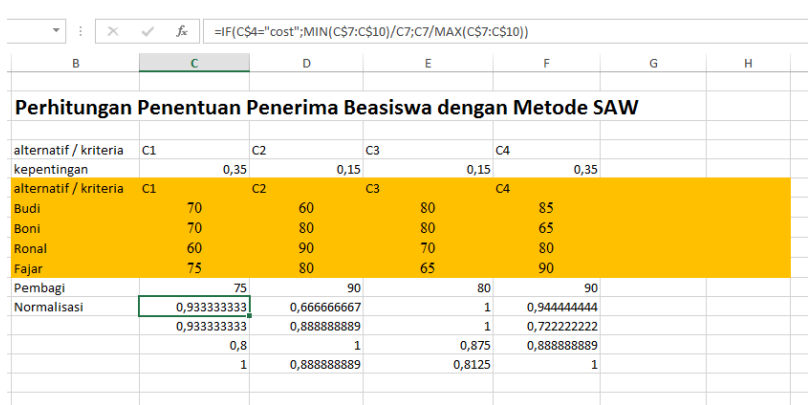

Tabel 6. Rumus dan Hasil

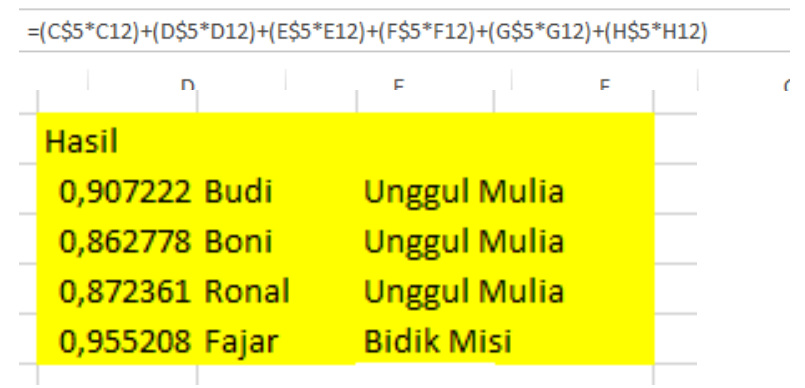

Dari perhitungan diatas diperoleh $75 \%$ mahasiswa baru memperoleh beasiswa Unggul Mulia dan 25\% Bidik Misi. Dengan perhitungan yang sesuai antara manual dan excel.

\section{KESIMPULAN DAN SARAN}

Dari rancangan sistem aplikasi penentu beasiswa menggunakan metode SAW di Universitas Widyagama, maka penyusun memberikan kesimpulan bahwa karya pengabdian produktif ini dapat digunakan sebagai media untuk menentukan penerima beasiswa sehingga tidak perlu mebhitung secara manual.

Dalam penyusunan konsep sistem penentuan beasiswa masih memiliki kekurangan, diharapkan kedepannya aplikasi ini dapat dikembangkan dengan lebih baik lagi. Mungkin dengan menambahkan fitur-fitur di dalam aplikasi yang terintegrasi dengan aplikasi.

\section{DAFTAR PUSTAKA}

[1] U.

W. Malang, "https://widyagama.ac.id/r2012/tag/beasiswa-unggulmulia-uwg/.".

[2] I. Darimi, "TEKNOLOGI INFORMASI DAN KOMUNIKASI SEBAGAI MEDIA,” vol. 1, pp. 111$121,2017$.

[3] I. Print, I. Online, M. Putri, W. Daratul, and S. Artikel, "Teknologi dan Sistem Informasi Perancangan Aplikasi Bercocok Tanam Padi dan Cabe Kriting Berbasis Android," vol. 02, pp. 306-312, 2017.

[4] J. Dasi, "SISTEM PENDUKUNG KEPUTUSAN (DECISION SUPPORT SYSTEM)," vol. 11, no. 3, pp. 77-90, 2010.

[5] S. Eniyati and C. Noor, "Sistem Pendukung Keputusan Penilaian Prestasi,” vol. XV, no. 2, pp. 136-142, 2010. 
